\title{
Exchanges
}

In the Exchanges, we present conversations with scholars and practitioners of community engagement, responses to previously published material, and other reflections on various aspects of community-engaged scholarship meant to provoke further dialogue and discussion. We invite our readers to offer in this section their own thoughts and ideas on the meanings and understandings of engaged scholarship, as practiced in local or faraway communities, diverse cultural settings, and various disciplinary contexts. We especially welcome community-based scholars' views and opinions on their collaboration with university-based partners in particular and on engaged scholarship in general.

In this issue, Natalia Khanenko-Friesen talks with Darrell McLaughlin of St. Thomas More College at the University of Saskatchewan. Darrell McLaughlin $(\mathrm{PhD})$ is an Associate Dean at St. Thomas More College, University of Saskatchewan.

\section{Conversation with Darrell McLaughlin, St. Thomas More College}

Natalia Khanenko-Friesen: Darrell, you have been working at St. Thomas More College (STM) for quite a few years and had an opportunity to oversee and observe the development of the Community Service Learning Program in the College from its inception. What attracted you to this kind of work in the first place?

Darrell McLaughlin: I farmed full-time and part-time for thirty years before coming to STM. During my fifteen year period of full-time farming, I was a farm and food activist in Atlantic Canada. It was then when

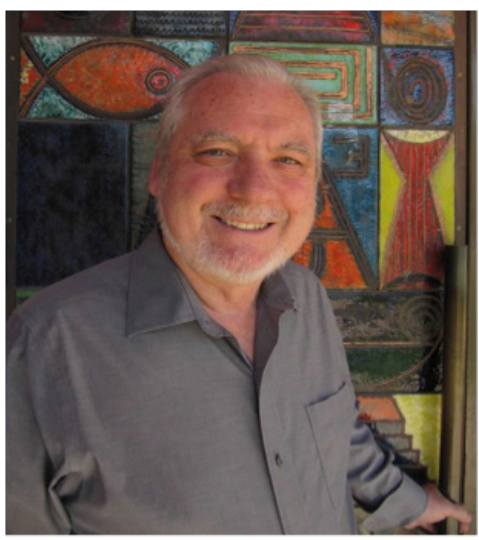
I encountered a fair bit of academic research that people in my community were hungry for. Unfortunately, there was equally or considerably more research that didn't seem to have a social purpose to us. So, I was attracted to STM initially because it was a Catholic Liberal Arts College, but once I came here the focus on social justice really allowed me to think about how I might contribute to the College. At that same time, we were just beginning with community service learning and engaged scholarship here. David Peacock was leading that, along with other administrative people at that time. They saw the need for connecting scholars with community. That just appealed to me, so as soon as the opportunity arose, I 
became involved.

There is also another dynamic at play - and that is the opportunities for students, their chances to do socially meaningful work have declined over time. Their participation in the economy is often reduced to part-time sales clerks or flipping burgers or serving coffee, those types of things. Not to say that this doesn't serve a social purpose - it does - but it doesn't necessarily inspire them or gives them the opportunity to engage with some of the big questions with which community organizations are engaging. Over the last twenty years there has been a move towards a new liberalism within the wider political context. Globalization has become synonymous with global capitalism and, as a consequence, the funding for community organizations has declined. Meanwhile, demands on community groups increased and at the same time I was feeling that students needed an opportunity to find a place to experience valuable social contributions. Those were the kinds of dynamics that informed my interests initially and they continue to inform and develop over time.

Natalia: How has CSL and CES work evolved over the course of your career at STM? What was informing the changes that took place?

Darrell: Globalization has continued, and by globalization I mean something more than global capitalism developing. Rather, I refer to globalization as the reduction in the rigidity of borders that affects information flows, physical distance, political differences, and the capacity for people and ideas to move, and in some cases, the necessity for people and ideas to move across what was formerly official borders. That resulted in a difference in community needs as well. We see a connection to different community partners shift as a consequence of demands on them, such as with the Saskatoon Open Door Society and International Women of Saskatoon. Those changes are very interesting to see. The rise in awareness of the incompleteness of our Canadian history - the stories we've told ourselves about that history, in relation not only to immigrants but also toward settler and Indigenous peoples' relations - has changed. We're giving students the opportunity to engage with that history in critical and meaningful ways so that they can understand their society and the times we live in, preparing them so they can make their decisions and choices they will need to make moving forward. Again, I see engaged scholarship allowing students to get a jump on understanding all those things that are going on. They can get a sense of where they might find careers, or at least research questions they can engage with at the university level. It simply makes their university education more meaningful.

The other thing that has emerged more prominently than what may have twelve years ago when we started engaged learning in the College is engaged research. Sometimes that happened to the detriment of engaged learning because the value that research has the potential to contribute. But if I have an aspiration about engaged scholarship, it would be that the two go together in concert. Engaged research has an opportunity to engage students more deeply in a learning process. At the university, there is a desire to have engaged research at a 100-level and to commission students into community, as well as

Engaged Scholar Journal: Community-Engaged Research, Teaching and Learning 
to have opportunities for faculty to develop partnerships that would expose students to gaining understandings of the context in which they live.

Natalia: The editors of this special issue, together with the contributors, were keen on identifying some particular, and perhaps unique, dimensions of community engagement in post-secondary institutions rooted in one or another faith tradition. Can you say that St. Thomas More College pursues community engagement differently from how it is pursued at its secular partner institution, $U$ of Saskatchewan? If yes, what lies behind these differences?

Darrell: That's an interesting question in part because I see the demand flowing out of our Catholic intellectual tradition, which informs what we choose to focus on. But it also has to do with having a distinct identity, to ensure that we are contributing to something unique to institutions of higher learning over and above of what happens within secular universities. This may be, to a less degree, unique from what happens at other Catholic institutions or even other faith-based institutions of higher learning. Any liberal arts institution will contribute to critical thinking, critical writing, good communication skills, and the ability to understand oneself within a wider context. Maybe it is a bit unique to our Catholic identity that knowledge isn't seen as an end in itself, but as a means to address social concerns. We are called to serve through our vocation as educators - to not only serve students, but to serve a wider social good. As a consequence, in addition to those things that other liberal arts institutions will contribute, I think there is a more explicit moral formation that takes place here. By moral formation, I am thinking about an ethical moral base on which students can find their place in the world. Here I am thinking about the role vocation specifically plays. Buechner defines vocation as the place where the heart's deep gladness discovers the world's deep hunger. If we can help students discover that, then they will find a fulfilling life-long process of learning and discovery. Without that, the search for meaning becomes very difficult. Engaged learning is one of the best ways that I know to help students understand the world's great needs, and that's how students can find personal meaning.

Natalia: In STM College, steeped in Catholic faith tradition, the concern for the common good borne out in service to others lies at the very foundation of education. This is possibly applicable to many other Catholic Colleges in Canada and elsewhere. Is there a shared conversation between Catholic Colleges and Universities in Canada on the meanings and applications of CSL and CES?

Darrell: Well, you have now brought us very quickly to the edge of where we are in the development of the engaged learning. The conversation about engaged learning across all universities is relatively new, having developed over the last 12-15 years. The establishment of your journal is quite recent but not only is it unique to Canada, but it is unique to 
the world. That shows the infancy of this type of conversation. There are attempts by groups across Canada to develop a community of best practices for engaged learning. As far as I'm aware, the reason such community networks are developing between Catholic institutions is because of the initiatives we had here at STM. We have reached out to other Catholic institutions across Canada to initiate a conversation, and to some degree it is successful (but perhaps not as much as I would have liked).

We had a session on campus two years ago where we invited people from Catholic institutions across Canada, and representatives from St. Peter's College (Munster, SK), Campion College (Regina, SK) and St. Michael's College (Toronto, ON) attended. It was a very fruitful conversation, but that conversation has pretty much stayed within that group. We had one follow-up meeting hosted by St. Mike's, but there hasn't been a sustained conversation beyond that. At an individual level, we have reached out to both St. Pete's and to Campion, and most recently to St. Mary's University in Calgary, to see if there would be some future possibilities. The conversation with St. Mary's has been the most encouraging. St. Peter's College is a small college that offers first and second year courses, so I can see where they have limited capacity to build up an engaged learning program. However, they can inform students who plan to come to the $\mathrm{U}$ of $\mathrm{S}$ about how they can later participate. In the case of St. Mary's, it's a comparable size institution - just a little bit smaller than us and our current President is their former President. It makes possible some relationships that we don't have with others. At this point of time, the conversation has focused on three areas. One area is the unique ability our institution, as well as St. Mary's, could contribute to our engaged learning abroad. St. Mary's does some unique things there and we do some unique things here, for example, our Intercordia program, our Summer Session in Ukraine. Meanwhile, St. Mary's has study abroad in Rome and as well as a biology class that goes to Belize, that is unique. So there are those types of possibilities. The other possibility would be to have block-transfer credits where we would put together a group of courses. Rather, each institution would put together a group of courses that would emphasize our unique and distinctive offerings or some of our distinctive offerings in a specific term that would then allow students to exchange between the two institutions. One for one would be ideal. And then a student would just take the accommodation area in the respective host city. The third would be a faculty exchange, which again would involve faculty teaching in distinctive areas coming and teaching at a host institution for a period. I would like to see that possibility open up for other Catholic institutions across Canada and, ideally, have one in each region that would allow students to gain a rich sense of the Canadian context in which they are living. Not only are we having more relations from one region to the world, but from our different regions in Canada to the world, that is changing over time too. So that type of the engaged scholarship I think would allow students to go volunteer with a community partner in these other institutions. It would broaden immensely the education and foundation that students would receive.

Natalia: What challenges CSL program has been facing over the course of its evolvement 
and today? Can you suggest the ways to overcome those challenges? What is one most important achievement that you can name when it comes to the work of CSL/CES at your College?

Darrell: The challenges have always been relationships - staying in relationships with community partners, sustaining relationships with faculty across the different demands, and the changse that come with cuts to community partners' funding, putting them in a less capable position to welcome our students. We have not always been in a position to offset those costs we add to the community partner when we send students there. Back when I first became involved, we had two occasions when students first come to attend a 'Community Plunge'. This is where the University covered the costs for community partners coming together for an orientation day for students. We would have twenty-some community organizations. Students would sign up for the concurrent sessions and hear descriptions of what goes on in each different community organizations. Students would then decide which organization they want to become involved in, and this orientation itself provided some powerful experiences. I had students in my classes go on two occasions, and I remember one student particularly. She wasn't quite sure what she wanted to do when she went to the Community Plunge, but she had something in mind. The event was hosted at The White Buffalo Youth Lodge. At the end of the day she said, "I want to volunteer here. I want to volunteer at The White Buffalo Youth Lodge". She was a student in my 100-level sociology course. It was a full-year course at that time, and it was such a privilege to read her reflections as she journeyed in her understanding. It is difficult to realize just how big a challenge she had set for herself. She described how she came from a very racist community, but she had the courage to say: "I am going to challenge this. I am going to be surrounded by people that I normally would not be surrounded by...I will work in a context that I would not normally find..." By the end of the year, she did not have all challenges addressed, but she moved from asking questions and challenging her assumptions to helping to challenge the assumptions of the community she was from. That's just one example of an opportunity for students to be exposed to a wider variety of community organizations - many of which they wouldn't have known existed, much less the reasons why they exist. Quite a few of our university students tend to be from fairly privileged backgrounds. And that can mean they are fairly uniform in the assumptions they have about themselves, as well as about others. Having the resources that we have in these types of partnerships, and to expose students to the diversity of social realities, is one of the big challenges.

If I think about the defining accomplishment of STM, it happened before me. It happened with the appointment of the Engaged Learning Coordinator. If I think about everything that has happened post-appointment, I would link it back to that point. As a faculty member, I would have neither time, nor courage, nor the sense of confidence to reach out to the community partners, to know the literature on the best practices or to begin to explore, or to have that sustained conversation with other colleagues - none of 
these would be possible without the anchor that is the Engaged Learning Coordinator. The college's commitment prioritized this and, as a result of its commitment to engaged learning, it set aside funding that allowed us to begin. It didn't cover all the costs incurred, but it became the foundation on which we could reach out to other donors that came on board. I'd say that was a key accomplishment. There have been so many other smaller accomplishments along the way. We just had the $10^{\text {th }}$ anniversary of the Intercordia program here, and alumni from across the years from the first year through to the current year were able to come together. I was just so impressed with the young people who were attracted and continue to be attracted to engaged learning. They likely would have been outstanding young people without the program, but it provided a home for them and a community in which to have sustained conversations about social concerns.

Natalia: In conclusion, given your experience in CES/CSL administration, what would you wish other colleagues involved in CES/CSL administration at other faith-based institutions?

Darrell: Without appearing to be prompted by you, I think contributing to your journal is one thing. Thinking about how scholarship can be shared with other people across the country and across the world is likely the best way to build a community of practice. Within that community of practice, we likely can start to imagine areas of expertise. Trying to be all things to all people is impossible. If we are able, within a community, it is best to have a division of labour. Not to the point where we become so rigid in boundaries that we cease to have conversations across those divisions, but to at least allow for more indepth development. The other thing I would like to see is a more explicit program where students, from their first year through to their fourth year, could experience different levels of engagement that would allow them to continue to grow very explicitly as engaged scholars. That doesn't necessarily mean that it would only be open to people that identify with, "I want to be an engaged scholar in year one". But for those who have become engaged in their first year, it would be wonderful to have an opportunity to engage in different levels of commitment and experiences throughout their time at STM. Perhaps we could award a certificate in Community Engagement, to mark the end of that time. Receiving such a certificate would represent a capstone experience involving a sustained internship with a community group. We have some fantastic community leaders here in Saskatoon - and I am sure it's the same across the country - who could serve as mentors to our students. That would be an untold benefit to the students, and it would give them a chance to give back to the community.

Natalia: What can you say about the dialogue between various faith institutions on the nature of CES? Does it exist as a dialogue? Is it meaningful, informative, enough?

Darrell: I don't think that this dialogue has been very systematic. I think it happened from time to time and likely this special issue of the journal may foster a dialogue that hasn't 
existed. My observation is that different faith-based institutions see engaged learning in different ways. Some of them will see engaged learning from the standpoint of charity, others will see it from the standpoint of service, and still others may see it from the standpoint of solidarity and a struggle for social justice. I would hope that people from all those different perspectives would find some common ground in that. I've come to see the different types of community engagement as not necessarily exclusive. I've come to see them as necessary at different points in time. Charity means responding to immediate needs within the community. Service is a chance for us to think about our gifts and the money that we might give to contribute to what community has identified as somewhat immediate or maybe intermediate needs. Solidarity requires us to think about the structural changes that are needed in the community for students to engage with the community partners. They have a chance to see all three of these opportunities to contribute. And I think our scholarship can contribute to those three areas as well. The degree to which different faith institutions feel comfortable engaging with one or all aspects of engaged scholarship is, I think, a meaningful pursuit.

\section{About the Contributors}

Natalia Khanenko-Friesen is a professor of anthropology in the Department of Religion and Culture at St. Thomas More College, University of Saskatchewan, and a founding editor of the Engaged Scholar Journal. Email: nfriesen@stmcollege.ca

Darrell McLaughlin is an Associate Dean at St. Thomas More College, University of Saskatchewan. His research focuses on the social relations producing the processes globalizing food systems and people's responses, with a special attention on fair trade, sustainable agriculture, globalisation, social justice, and food sovereignty. He comes from a background in farming and farm activism. Recent publications include: "Program Evaluation and Impact Assessment in International Non-Governmental Organizations (INGOs): Exploring Roles, Benefits, and Challenges" with Stan Yu (lead author), Canadian Journal of Nonprofit and Social Economy Research (2014); "Gender, health, labor, and inequities: a review of the fair and alternative trade literature." Agriculture and Human Values (2012) with Terstappen (lead author) and Hanson; with Daniel DeLury "When elephants no longer dance: Constructing sustainable, socially just agricultural policies in Saskatchewan" in David McGrane (ed.) New Directions in Saskatchewan Public Policy (2011). Email: dmclaughlin@stmcollege.ca 